\title{
$\widehat{A}$ Madridge \\ madridge Journal of Cancer Study \& Research \\ Interconnecting Scientific World
}

Review Article

Open Access

\section{Historical-Clinical Pathways to a Cancer Holistic Perspective}

\author{
Marco Balenci ${ }^{1-3 *}$ \\ ${ }^{1}$ American Psychological Association, Washington, DC, USA \\ ${ }^{2}$ Italian Association of Analytical Psychology, Rome, Italy \\ ${ }^{3}$ International Association for Analytical Psychology, Zurich, Switzerland
}

\section{Article Info}

\section{*Corresponding author:}

Marco Balenci

Italian Association of Analytical Psychology (AIPA)

Florence

Italy

E-mail: marco.balenci@gmail.com

Received: January 13, 2019

Accepted: February 2, 2019

Published: February 14, 2019

Citation: Balenci M. Historical-Clinical Pathways to a Cancer Holistic Perspective. Madridge J Cancer Stud Res. 2019; 3(1): 85-96.

doi: $10.18689 /$ mjcsr-1000113

Copyright: (c) 2019 The Author(s). This work is licensed under a Creative Commons Attribution 4.0 International License, which permits unrestricted use, distribution, and reproduction in any medium, provided the original work is properly cited.

Published by Madridge Publishers

\begin{abstract}
A historical reconstruction of the holistic approach to cancer is presented. A particular attention is given to the United States, since, after reductionism had prevailed in Western world, New York Jungian psychoanalyst Elida Evans published the first modern monograph about the psychology of cancer patients in 1926, proposing a holistic view of cancer again. Evans' theory has largely influenced cancer psychosomatics. Without pretension of completeness, research on cancer is discussed in its epidemiological, social, environmental, behavioural, and psychoanalytical aspects. The results of psychoneuroimmunology and the discoveries of developmental psychobiology are highlighted for their importance in a holistic vision of cancer. Assumption of this paper is that persistent dualism - studying body or mind - is depriving research of fundamental variables involved in human cancer; therefore, integrated multidisciplinary investigation is advocated.
\end{abstract}

Keywords: Cancer Psychosomatics; Carcinogenesis; Elida Evans; Holistic Medicine; Psychoneuroimmunology; Psycho-Oncology; Type C Behavior.

\section{Introduction}

The wholeness of patients was questioned soon in Western medicine, since the division between body and soul carried out by the philosophy of Plato, where soul is the essence of man and his body is only matter. In the 17th century, Descartes replaced Platonic-Christian dualism with res cogitans and res extensa. From then on, mind-body dualism has been the philosophical reference of medicine, that has developed from anatomical dissection to physico-chemical reductionism, started in 1847 Germany. Osler followed this German trend and his line brought American academic medicine to become an experimental science, on reductionist and exclusively biological positions [1].

The word Ganzheit (wholeness, totality) appeared in the German language only in the twentieth century, for the need to define a conceptual counterpart to "specialization" [2]. The concept of holism was introduced by Smuts, in 1926, as a dynamic and synthetic principle linked to the evolutionary process [3]. Regarding cancer, we find holistic observations until the 18th and 19th century, beginning from Galen's theory of a pre disposition to cancer of melancholic women. Some 1800 physicians reported life situations and particular emotions in future cancer patients: the loss or separation of a significant person, but also the frustration of life goals, involved a reaction of despair and hopelessness - negative emotions that were considered "the precursor of the neoplastic state" [4]. In 1844, Walsche's most authoritative cancer treaty of the 19th century included social conditions, temperament and mental affliction among the predisposing causes to cancer [5]. 
Attention to patients' psychosocial aspects was lost with the rise of reductionist medicine and the successes of cell biology. Further, promising therapeutic results of surgery and radiation contributed to regard cancer as a localized disease: thus, "the neoplasm was more and more considered as a problem of a specific body area, not of the body as a whole" [6].

\section{The Beginning of American Psychosomatics}

In the United States, medicine has remained predominantly dualistic and reductionist, intensifying experimental methodologies with increasingly sophisticated technologies [7]. On the side of mind, the turning point for "the somatic style" came from France. William James' Boston School of Psychopathology [8] formed a Charcot's Axis (1882-1920) [9] with French, British, and Swiss scholars. Among the latter, Carl Gustav Jung, clinical director in the Burghölzli Psychiatric Hospital of Zurich University, had become famous in America before coming into contact with psychoanalysis [10] because of the results of his experimental researches [11]. In 1909, with Freud and Ferenczi, Jung lectured at Clark University, where they met James, Hall and Putnam [8]. In 1911, the practice of a modified form of Jungian analysis began at the Massachussets General Hospital in Boston [12]. In 1912, Jung was invited by Smith Ely Jelliffe to lecture at the medical school of Fordham University (they had met in 1907) [13].

Jelliffe was a New York neurologist and Professor, one of the first American psychoanalysts; he is considered the father of American psychosomatics [14] and maintained an exchange of letters with both Freud and Jung, even after their detachment [15]. Regarding the mind-body problem, Jelliffe was a monist as was Adolf Meyer, Professor at Johns Hopkins and the most important American psychiatrist in those years. Meyer - with a term already used by Bernheim in France defined his holistic conception psychobiology and saw the individual as "a psychobiological whole" [16]. Accordingly, Adolf Meyer tried to convince physicians that they should consider both biologic and psychologic influences on illness. He constructed a chart to record the major life events. He included the calendar years of the patient's life-span, important life events, the patient's emotional reactions to those events, and illness experiences through the patient's lifetime [17].

Jelliffe was a convinced representative of the American psychobiological tradition and an innovator who criticized that no psychological methods were added to cancer research [18]. His being an advocate of holistic medicine made him feel very close to Groddeck and Jung, how one can understand from Jelliffe's letters to them [15].

Actually, Groddeck and Jung (though without having contact with each other) had a very similar conception of totality of man, expressed by their most important notion Groddeck's Es (It) and Jung's Selbst (Self) - with a clinical relevance both for psychopathology and for organic diseases.
Groddeck and Jung shared a holistic vision, but also monism and finalism - so with a position opposite of Freud, who was dualist and causalist, and extraneous to the concept of totality [19].

\section{Evans' Theory about Cancer}

Considered Jelliffe's openness of mind, it is not surprising that, in 1915, Elida Evans - a lay analyst trained at the "Zurich School" - asked Jelliffe to work with him. Evans became Jelliffe's assistant, then a collaborator: they did research and wrote together two psychosomatic papers, on chronic skin disease [20] and pulmonary tuberculosis [21].

In 1926, Evans published A Psychological Study of Cancer, the first modern work with a psychosomatic approach to tumours, based on around one hundred clinical cases [22-23]. Evans interpreted the psychology of cancer patients in the light of Jung's Psychological Types [24], published in 1921. Evans knew she was going against the current to study cancer from a psychological point of view, because she was perfectly aware that the "medical profession has been rather reluctant to search for other than physical causes" [22].

Evans collected the detailed personal data of each cancer patient, adding "the emotional history of the individual" [22] to the classic clinical anamnesis, modifying Meyer's aforementioned methodology by a psychoanalytic approach that emphasized the patient's inner experiences. For each patient, Evans gathered carefully a clinical history and a biographical history: two histories which have become a model in cancer research, followed by authors like LeShan $[25,26]$ and Chiozza [27]. Evans related to the patient as a psychophysical totality and dwelt on the fact that cancer is mainly a disease of the second part of life - which is of particular importance in Jung's theory of individuation.

Evans connected carcinogenesis to the destructive aspects of the collective unconscious, a very deep psychosomatic level of phylogenetic origin where psychic contents blend with instincts. The collective unconscious is genetically inherited with the brain and is a biological entity that affects both body and mind, physiology and ideas: in 1936, Jung defined its archetypal elements "patterns of instinctual behaviour" [28]. The biological insights of Hediger [29] and Portmann [30] found similar nervous structures in animals for species-specific actions; moreover, ethologist Lorenz [31] studied the open programme of behavioural mechanisms that are phylogenetically inherited, introducing the concepts of innate releasing mechanism and scheme. More recently, the collective unconscious was approached to ethology and Mayr's open program [32] by Stevens, who described the archetypes as "phylogenetically acquired, genome-bound units of information which programme the individual to behave in certain specific ways while permitting such behaviour to be adapted appropriately to environmental circumstances" [33].

Obviously, Evans' understanding of the collective unconscious did not include the knowledge of DNA but it was based on Jung's evolutionist approach. For carcinogenesis, 
she suggested a regressive energy process to collective unconscious because of traumatic events in individuals who are marked by social conformity for the need to maintain their relationships, relinquishing any form of personal creativity. Evans claimed these patients had an extrovert onesidedness, a completely turned outward attitude that prevents other psychological adaptations, included those towards internal stimuli. This kind of person does not show negative emotions and instead "gentleness and mildness, the lack of self-assertion" [22], showing an anaclitic behaviour [23]. Consequently, the ego is rigid and fragile, unable to cope with the manifold demands of life. The loss of the object of external dependence, hence, becomes a dramatic fact which pushes the individual to despair - "a renunciation, a giving up of hope", "a total destruction of hope" [22] - until psychobiological collapse: a withdrawal from life without conflict that initiates an unconscious suicidal process.

Evans' "psychosocial approach to cancer" encountered strong resistance from medicine, whose reductionist model does not recognize "that life is based on mutual transactions between two or more living organisms, on field phenomena" [34]. For more than twenty-five years Evans' study had no continuation [35]. Therefore, when even the members of the American Psychosomatic Society did not show interest for cancer, George Engel decided to discuss "Neoplastic disease and psychological process" in the 1954 Society's Meeting. Engel noted that, although "our belief that all diseases are 'psychosomatic', in the sense psychological processes are always involved", this was not true for cancer, which had not publications in the Society's journal nor a concern for its emotional aspects [36]. Engel's position did not produce many results toward cancer psychosomatics in America, and the situation was not very different abroad [34].

In Germany, nevertheless, there has been a line of holistic medicine starting from Groddeck's [37] speculations (also about cancer) [38] to Gestaltkreistheorie [39] and beyond. Along this line, Kaelin and Suchantke [40] saw cancer as a disease of the whole organism and created the concept of "cancer psyche" between the 1930s and 1950s. Their results are very similar to Evans' observations and to cancer studies before the twentieth century.

\section{Research at the University of Rochester and Psychoneuroimmunology}

Psychoanalysis "was the only dynamic language of inner experience allowed entry into the ultra positivistic scientific era" of 20th century United States [9,41]. Engel was a Freudian psychoanalyst at Rochester school of medicine, who created a holistic theory to overcome an exclusively biologic and mechanistic vision [42]. He began to develop his biopsychosocial model in the 1950s [43], realizing that the prevailing biomedical model - reductionistic, physicalistic and dualistic - needed to be supplemented by psychological, environmental and social factors to better understand and restore the patient's health.
Engel's approach to "the psychobiological unity of man" concerned medicine in general [44], and saw every disease as conditioned by psychosocial factors [45], including cancer but also mental diseases [46]. He expanded the role of depressive emotions: the affective states of helplessness and hopelessness became part of a non-specific condition called "giving upgiven up complex", seen as a contributing factor to the emergence or aggravation of diseases [47]. This complex occurs when the mind is unable to cope and the "conservationwithdrawal" biological pattern come into operation through the parasympathetic nervous system, altering body homeostasis with anabolic processes and so facilitating disease to develop [48]. Therefore, Engel suggested a second innate reaction pattern, in addition to "fight or flight" [49] (caused by anxiety and anger), which instead activates the sympathetic system with catabolic processes.

Engel's team predicted cancer in biologically predisposed women on the criteria of hopelessness prone personality or recent feelings of hopelessness [50,51]. However, nonspecificity of the giving up-given up complex left unresolved the reason for the onset of cancer instead of another disease. Nevertheless, Engel's biopsychosocial model constituted the theoretical framework [52] for psychoneuroimmunology (PNI), a holistic discipline started in 1975 [53] - that is also the year of the formal beginning of American psycho-oncology [54].

In 1981, Robert Ader - he too at Rochester - edited the first results of PNI research on the interactions between psychosocial factors and the nervous, endocrine, and immune systems, providing evidence of continuous information exchange among these systems through neurotransmitters, peptides and hormones [55]. A large body of research documented the presence of neuropeptides and their receptors throughout the body, with "nodal points" in the CNS: the limbic system, the dorsal horn of the spinal cord and the peri aqueductal gray region of the brain stem; but also in the entire gastrointestinal tract, glands and mobile cells of the immune system - thus configuring an extended physiological basis of emotions [56]. It was also discovered that the immune system can produce neuroendocrine peptide hormones and nerve cells produce immune-associated cytokines, proving the total integration of the immune and neuroendocrine systems which control each other in a bidirectional regulatory circuit $[57,58]$. The holistic concept of a unified psychosomatic network on the basis of PNI has therefore been affirmed [59]. Besides, studies have been performed to show psychological or behavioural influences on immune system, contributing to cancer incidence or progression through alterations of NK cell activity and in DNA repair $[60,61]$.

Interestingly, psychoimmunology is a term used by Solomon since the early 1960s (about twenty years before Engel and Ader) at Stanford University [62,63]. U.S. Department of Health officially admitted immunotherapy as a cancer cure from 1992 and published the results of research on neuroendocrine-immune-behaviour interactions [64]. In 1994, a book about the psychoimmunology of cancer was published and its 2002 second edition [65] provided a growing 
supportive evidence of the biologic mechanisms underlying the relationship between psychological factors and the immune system in cancer onset and progression.

\section{Psychoanalytical and Behavioural Research on Cancer}

In 1953, a symposium was held about psychological variables in cancer: the role of emotional factors on organic defences was discussed and Cutler expressed the idea of cancer "as a form of passive suicide" [66]. Later, there were three international conferences - 1963 conference in Cambridge, England [67]; 1965 and 1968 conferences in New York $[68,69]$ - where important contributions were made. Lawrence LeShan, Claus Bahnson and Marjorie Brooks Bahnson intervened at all three conferences.

LeShan - a New York clinical psychologist - is considered a founder of American psycho-oncology, on which he has worked since the 1950 s also studying the historical precedents of the subject $[6,70]$. We can see LeShan as the prosecutor of Evans' work on cancer; in fact, he cited her book and also referred to Jung's ideas. From his psychotherapeutic sessions, LeShan [71] learned that cancer patients have had a weak "will to live" even before becoming ill. He attributed this deficiency to an excess of adaptation: future patients live "otherdirected", namely they are more concerned of others' opinions rather than the needs of their own self. Thus, LeShan resumed Evans' line and linked cancer to the neglect of that "inner development" which is Jungian individuation. LeShan followed Evans also regarding future cancer patients' loss of one intense emotional involvement (situation or relationship) as a crucial moment of existential crisis that deprives them of life's meaningfulness [26]. This is the theoretical basis of LeShan's psychotherapeutic techniques (crisis therapy), addressed to increase the will to live in cancer patients but also as a preventive method "to help those persons whose personality patterns and life history might make them especially vulnerable to cancer" [26]. Actually, LeShan's research led him to hypothesize an emotional life-history pattern associated with neoplastic disease [72], a vision very similar to that of Evans; but LeShan, unlike Evans, has backdated the presence of feelings of isolation and despair since patients' childhood, a position that makes him close to Baltrusch $[73,74]$ and is confirmed by further research [75].

Bahnson and Bahnson criticized the delay of medicine for a holistic view of disease [76] and suggested a monistic approach [77] such as Grinker's [78,79]. The Bahnsons introduced a global psychobiological approach which admitted neither physiological reductionism nor psychologism. Accordingly, they rejected Cartesian dualism, looking at physiological and psychological phenomena as complementary representations and developing "a social-psychological-somatic theory [...] encompassing both behavioral and somatic processes within one framework" [80].

The Bahnsons interpreted the depressive behaviour in future cancer patients as a "syndrome of barrenness" due to strong and persistent defences of repression and denial in individuals with psychological aspects of extroversion and lack of inner resources. These persons' childhood is characterized by dependency and they become rigid and constricted adults with an impersonal reality orientation. To the Bahnsons, future cancer patients develop two selves completely distinct and strangers to each other: "The conscious self is socially adequate, but empty and meaningless. The unconscious self is explosive, tragic, and tormented" [81]. The Bahnsons assumed that cancer patients make use of projective defences less than normal individuals do and see their environment too positively due to a strong repression $[82,83]$. The Bahnsons referred to psychoanalytical egopsychology for their model of psychophysiological complementarity, which is holistic: each disease is seen as the mere manifestation of "a total psychobiological process" with isomorphism between psychological and biological processes.

Starting from the 1950s, American Internal Medicine "moved in a biochemical and generally reductionist direction, separated itself from organismic physiology, and disconnected from psychiatry." Thereby, even the diseases once considered "classical" psychosomatic were treated in a reductionist way, until the "molecular revolution" arrived in the 1970s [1]. A "neo-somatic style" imposed itself and the psychoanalytic model in psychosomatic medicine was questioned as a clinical methodology often without scientifically verifiable procedures [84].

Also the notion of psychosomatic cancer was criticized, so research and clinical practice shifted from the etiological role of emotions to the emotional consequences of being sick and anti cancer therapies, with the aim of improving patients' lives. The new sub specialty of psycho-oncology developed instruments to study subjective symptoms of pain, anxiety, nausea, depression, delirium. Moreover, consultation-liaison psychiatry spread, exploring comorbid mental disorders for their treatment [54].

Placing psychoanalysis in the background, "clinicalanamnestic methods" were abandoned for the benefit of laboratory and psychometric testing [1]. Along with psychoanalysis, interest in the inner experience was put aside. Thus, social aspects predisposing to diseases were studied and patterns of behaviour were sought, bringing in the 1970s a renewed impetus on the psychosocial aspects of cancer with Behavioral Medicine, based on the biopsychosocial model [85]. And with a behavioral approach a Type $A$ behaviour was discovered in competitive, tense, anxious, hostile, self-centred people, who were predisposed to cardiovascular diseases. Type $B$ was instead called the behaviour of uncompetitive and relaxed individuals who were not prone to heart problems [86].

Lydia Temoshok - a psycho-oncologist in Behavioral Medicine - had long studied melanoma patients [87] when she began a research on cardiovascular patients (Type $A$ ) realizing that their behaviours were the opposite of each other [88]. Therefore, she worked to define the characteristics of a specific pattern of behaviour for cancer patients [89] and called it Type $C$ [90]. In the same years, this pattern was 
developed independently by London psychiatrist Steven Greer [91,92]. Interestingly, the evolutionary approach to social behaviour has provided a possible explanation for selfish assertiveness and altruistic cooperation - referable to Type $A$ and Type $C$ - as selected forms of adaptation to the environment in individuals defined respectively proselfs and prosocials [93].

Temoshok explained that Type $C$ is not a personality but a behaviour pattern, a coping style: contrary to Type $A$, this behaviour is cooperative, appeasing, self-sacrificing, un assertive and free of negative feelings. It is a product of adaptation started in childhood, a condition devoid of depressive symptoms but characterized by "non expression of emotions", that may be more or less rigid. To Temoshok [90], a total control over emotions leads to not knowing one's needs and to induce an unconscious suffering, until a "sort of quiet desperation - a form of hopelessness - [which] has been shown to damage the immune system". She called it a "hidden hopelessness" and claimed that a life long Type $\mathrm{C}$ behaviour "can cause a generalized deficiency in the cancer defense system."

According to Temoshok, there is not a causal relationship between Type $C$ and cancer, but this behaviour is a "risk factor" that can play a more or less significant role within the theoretical contest of Engel's biopsychosocial model. Her research was conducted with a rigorous methodology, finding evidence that non expression of emotions is the toxic core of Type C [90], associated to reduction of lymphocytes and faster cell multiplication in the tumour site. It has been proved that "Type C coping - non-expression of emotions, stoicism, and a passive coping style - is a risk factor for disease progression or less favorable survival outcomes among cancer patients" [94].

Temoshok's theory is composed by the results of previous studies combined with her findings: features of Temoshok's behaviour pattern can be traced back to the traits identified by Evans. Temoshok did not cite Evans, who is however present in a historical article by LeShan [6] quoted in Temoshok's book [90], but Evans' priority in several aspects of Temoshok's theory is evident. Moreover, referring to the work of LeShan and the Simontons, Temoshok indirectly adopted Jungian concepts such as "inner guide" [95] (the Self) [96], "guided imagery" (active imagination) [97], and "creative expression." Evans, following the Jungian notion of instinctive creativity, described cancer as a pathological manifestation of "creative urge" to be balanced [22]. In 1936, at Harvard University, Jung would state: "Creation is as much destruction as construction" [98].

\section{Social Factors}

Since Evans' book, an interpersonal dimension - alien to the biomedical model - has been introduced in modern cancer research. A sociological expression was used for cancer patients [90]: they live "other-directed" by social norms or the central people in their lives. However, Riesman [99] considered the other-directed type to be a character of contemporary
Western humanity, and of Americans in particular: this widespread dependence is progressively internalized since childhood, leading to "an exceptional sensitivity to the actions and wishes of others" and to "a close behavioral conformity". This existential attitude proposed by Riesman corresponds to what Evans called one-sided extroversion. Evans herself had highlighted the increasing risks to move away from a natural life and called cancer "a disease of civilization", followed by others claiming that cancer is "a symptom of a losing existential encounter between the world and a person predominantly identified with the spirit of the industrial age" [34] and that "cancer goes together with mass society" [100].

This social vision of cancer must be included in the more general criticism of contemporary Western lifestyle, what Jung [101] did with an evolutionary approach. Suchlike remarks also came from Neumann [102], Lorenz [103], and Stevens [33]; while Fromm [104] described automaton conformity as the most important mechanism of escape for normal people in modern society. To Fromm, automaton conformity can be assimilated to animal mimicry, a form of extreme social adaptation that makes an individual identical to others for eliminating anxiety, at the price of depriving him of his original self. Fromm's pseudoself corresponds to the Jungian concept of pseudoego, a rigid and fragile ego where only an external orientation is possible, so what happens inside (in the body, too) is not recorded [105]. Pseudoself and pseudoego are linked to overadaptation to the outside world, a status already called into question by Evans and later by Ammon for psychosomatic patients [106].

It is worth noting a convergence between psychological and sociological studies, which leads to a continuity between pathological inner experiences and adaptation mechanisms in industrial societies, so much to hypothesize that certain characteristics of contemporary society are carcinogenic.

\section{Epidemiology}

Cancer is more widespread in industrial societies than in rural areas, but this fact has not a single explanation. In the United States, the need to carry out a survey on lifestyle and environmental factors led to 1981 Doll and Peto's national study [107]. In their assessment of the known risks of cancer, Doll and Peto had expressed percentages that proved substantially similar in the reviews carried out 35 years later [108]: tobacco smoking is the most important avoidable cause with $30 \%$. Doll and Peto had assumed between $10 \%$ and $70 \%$ the estimate related to diet and their average risk of $35 \%$ was questioned [109], bringing the percentage to $20 \%$ despite the correlations recently demonstrated for lack of physical activity and obesity, red meat intake, and Helicobacter pylori infection. This lower estimate was, however, criticized because it did not include the effects of early-life over nutrition - in utero and during growth - on adult cancer risk [110].

In 1982, a specific research program about the role of diet in carcinogenesis was indicated [111], highlighting two aspects: the abundant use of fat and meat in Western diets is correlated with colon and breast cancer [112]; migrants take 
the cancer risks of the country where they go and eat, thus minimizing the role of genetics in carcinogenesis $[113,114]$. Therefore, it became important to investigate cancer incidence in different countries [115] and to compare the effect on health of a diet low in fat and high in vegetable, common in non-industrialized areas.

A member of 1982 Committee, T. Colin Campbell, became the project director of the China-Cornell-Oxford Project on nutrition, environment and health, a long research carried out through two surveys (1983 and 1989) in rural China [116]. The China Project's results [117] and further studies have led to evidence that correct dietary practices may reduce cancer risks [118], "diet does play an important role in the cause and prevention of cancers" [119] and "nutrition and life-style factors may be determinants of up to $80 \%$ of large bowel, breast and prostate cancer cases and of one third of all cancer cases" [120].

The data on the role of diet in carcinogenesis with greater convergence can be summarized as follows [121,122]: a modern Western nutrition - characterized by high intakes of meat, dairy products, sugar and refined carbohydrates, and by micronutrients deficiency - may be a major determinant of risk, especially associated to an excessive caloric value resulting in over-weight or obesity. The latter are the most important avoidable causes of cancer, after tobacco. In particular, high consumption of animal fats and preserved or red meat is strongly connected with colorectal cancer. Alcoholic beverages, salt preserved food, and some chemical substances are also considered important risk factors. In reverse, physical activity along with a high intake of fruit and vegetables (at least $400 \mathrm{~g}$ per day) besides dietary fibres and micronutrients (such as vitamins and trace minerals) are believed to decrease the risk of cancer.

These findings have been substantially confirmed to date by the 2007 WCRF/AICR review [123] and its 2018 updating [124], that interestingly passes from the identification of specific dietary factors in causing or protecting against cancer to a "more holistic focus on the determinants of resilience to external and endogenous challenge". From this new perspective, it is the metabolic state of an integrated pattern of behaviours (consisting of diet, physical activity, and many other variables) which determines the conditions that may lead to cancerous changes. Therefore, the 2018 WCRF/AICR's approach examines the individual "way of life" overall (and no longer just specific foods or nutrients), going in a holistic direction.

\section{Environmental Influences on Health}

In 1935, Jelliffe [18] defined ecology as the study of "adaptation of man as a whole to the whole of the cosmos" and proposed medicine to be a branch of ecology: to him, chemical, biological and psychological levels together can explain the whole individual. Jelliffe deemed the application of the ecological principle as the best approach for future medicine, in order to understand diseases in individuals who must continually adapt to their environment.
Jelliffe's extraordinary foresight is taking shape in the recent turn of immunology, which has added an ecological perspective to its classic defensive function. As regards the latter, the specific immune dysfunction in cancer was defined as an "underactive" immune system [125]. Further, a mutation theory of cancer has been formulated, in which the pathogenic mutation is caused by environmental carcinogens or viruses, but also by error proneness in replication and repair of DNA, especially in aging when a progressive reduction of the immune system efficiency occurs [126].

Taking the holistic approach of systems biology, ecological immunology [127] has expanded its investigation from individuals to their environment. Since the immune system receives and processes molecular information from both organism and environment, it has been assimilated to cognitive functions $[128,129]$. The immune system was, therefore, called mobile brain [130] and, for its integration with the psycho-neuro-endocrine system, forms an extremely complex cognitive system. Therefore, eco-immunology can also be included among environmental sciences [131].

Mother is the first environment in human life [132]. Her antibodies prime child's immune system since intrauterine life, so mother's immune experience conditions early immune development [129]. However, research has showed that relationships regulate other biological processes in early childhood. After Spitz's study on anaclitic depression [133,134], and Harlow [135,136] and Bowlby's [137] ethological research on maternal separation and loss, Hofer conceived animal and human attachment as a regulatory process "by which the mother serves as an external regulator of the infant's behavior, its physiological state, and even the neurochemistry of its maturing brain" [138]. Therefore, Hofer has hypothesized that effect of an early separation may be an emotional and physiological vulnerability to diseases in adulthood over the life span, caused by an altered course of development $[139,140]$. Actually, infant separation causes alterations in metabolism, sleep, and in cardiovascular physiology, but also reduced secretion of growth hormone and decreased T-cell activity [141-142]. Thus, Hofer argued that the normal mother-infant interaction contains hidden biologic maternal regulators, to be added to the more known psychological aspects. Field $[143,144]$ claimed that a behavioural and biological dysregulation occurs both for the caregiver's physical or emotional unavailability: thus also hostility, rejection, neglect and abuse against the child [145] should be included among the causes of psychophysiological disorganization.

Moreover, Hofer [141] noted that the "infant responses to maternal separation closely resemble adult responses to bereavement" and that homeostatic regulatory systems remain under environmental influence in adulthood; accordingly, attachment relationships represent a strong environmental regulator throughout life, whose cessation causes a biobehavioural dysregulation. There is also supportive evidence that the death of a partner is associated with an alteration of endocrine and immune functions, and 
greater vulnerability to diseases $[146,147]$. Schore has recently claimed that the most potent environmental events are "emotional transactions" [148].

The modern practice of "depersonalized nursing" was considered an important environmental factor accounting for the rise of cancer in industrial societies [34], and family emotional climate has been associated to cancer $[149,150]$. Further, an integration between attachment theory and Type $\mathrm{C}$ behaviour was proposed to examine relational processes in cancer [151].

\section{Theoretical Discussion}

In 1986, the PNI realization of a communications network through neuropeptides induced Pert to question dualism, because mind and body "are best understood as an integrated entity" [152]. Twenty years before, von Bertalanffy [153] had argued that the Cartesian dualism between matter and consciousness was no longer adequate to scientific knowledge, and the concept itself of the unconscious did not find a place in this dualism. von Bertalanffy was referring to an unconscious inside a brain-mind, instead it has become necessary to take into consideration a widespread somatic unconscious and cognitive functions extended to the immune and endocrine systems, so that a new configuration of the human organism emerges where is not possible to establish an actual boundary between mind and body.

Before current experimental confirmations, Jung had a monistic and holistic conception based on his clinical method and studies on medicine and psychology in Western and Eastern culture. Jungian dual-aspect monism developed with the collaboration between Jung and the Nobel laureate in physics Wolfgang Pauli. This version of monism is based on quantum theory [154] and its main notion is complementarity (introduced by William James into psychology in 1890 and imported into physics by Niels Bohr in 1927 [155]): mind and body are conceived as complementary aspects of a same reality: the totality of the individual. Jung hypothesized a specific interconnection between matter and psyche - acausal and meaningful - which he called synchronicity [156]: this principle is able to explain "the co-ordination of psychic and physical processes in a living organism" better than a causeeffect relationship [157]. The importance of psychobiological synchronicity for cancer was discussed by Booth [34].

In dual-aspect monism, the individual is considered a psychophysically neutral domain - neither mental nor material. The Bahnsons' aforementioned model presents similarities with Jung's conception, since it sees physiological and psychological phenomena as complementary representations of a process taking place "synchronously, not conceptualized within a Cartesian parallelism, but within a monistic and 'total' configuration" [77]. Moreover, their notion of interpersonal and intrapersonal functions is close to Jungian extraversion and introversion.

Having detected these theoretical affinities, Balenci $[23,158]$ integrated the Bahnsons' model with Jungian attitude-types into an integrated model of diseases, which connects one-sided introversion to the Bahnsons' psychological axis, and extroversive one-sidedness to their somatic axis. Balenci started from Evans' emphasis on onesided extroversion as an energetic imbalance from psychophysical homeostasis and interprets cancer as a psychosis in the body, an isomorphic view shared with Goldberg [159].

Jungian attitude-types were checked by some scholars [160] and experimentally validated by Eysenck [161], inserting them in his psychometric scales that proved a higher extraversion score in cancer patients since the 1960s research of Kissen and Eysenck [162], Coppen and Metcalfe [163], and Hagnell [164]. Eysenck developed a research - first with Kissen and then with Grossarth-Maticek [165] - on the connections between personality and cancer, predicting cause of death based on psychosocial data 14 years ahead [166].

In the literature on cancer, however, a much more debated concept is stress. Since Selye's description in $1936[167,168]$, the general adaptation syndrome has been widely used to explain effects on immune function facilitating the onset of infections and diseases, including cancer. Actually, acute stress has salubrious adaptive effects, while, on the contrary, chronic stress can disturb or suppress immune function [169]. There is also evidence, both in animals and in humans, that stress at an early age (since the neonatal period) affects the baseline characteristics of the stressor-induced responsiveness of the brain $[170,171]$. Consequently, research has been undertaken to understand the effects of childhood trauma on behaviour and health in adulthood. The Adverse Childhood Experiences (ACE) study has provided an enormous amount of data proving the link between early stressful experiences and chronic diseases as adults, like depression, heart disease and cancer [172,173]. In particular, ACEs have been associated with the risk of lung cancer, depending on an increased smoking behaviour, but it has been assessed that additional mechanisms may exist [174]. Accordingly, a review of numerous studies on longitudinal associations between stress and cancer demonstrated that "stressful life experiences are related to poorer cancer survival and higher mortality but not to an increased incidence. Stress-prone personality or unfavourable coping styles and negative emotional responses or poor quality of life were related to higher cancer incidence, poorer cancer survival and higher cancer mortality" [175].

Therefore, we must argue that cancer onset is not dependent on stress alone but requires other factors. This is also Garssen's conclusion, suggesting to consider interaction with social support and coping style [176]. Thus, "Stress per se is not a critical factor" [91]: it can play a role in increasing the risk of infections, allergies, autoimmune and cardiovascular diseases, but a direct link between stress and cancer is not proven [177]. Cunningham expressed a shareable point of view: "While 'stress' is a useful catch-all to describe the stereotyped response to a variety of threatening stimuli, it is too broad to account fully for many of the changes that underly specific psychosomatic pathways" [178]. 


\section{Conclusions}

A holistic approach to cancer requires a holistic model of medicine [179], which is more suitable than the biomedical model to address the whole patient. Scholars such as Bahnson [80], de la Peña [180], Pert [181], LeShan [182], Solomon [63], have embraced this orientation. Greer and Watson [183] suggested that the failure of "an integrated psychobiological control system" permits cancer growth and spread; this kind of models shift cancer from a local phenomenon to a systemic disease - a holistic perspective justified by the aforementioned interdependence of organism systems and the hypothesis of an organizing centre $[128,129]$ or an inner guide $[19]$.

Organisms - as open and active systems [184] - present features of organization, regulative capacities, increasing differentiation and tendency to self-organize. The human organism is a system in exchange of matter and communication with its environment, presenting the specificity of symbolic activities: in humans, the flow of incoming and outgoing information is conditioned by an individual attribution of meaning. Such uniqueness greatly complicates patients' assessment, even for the same disease. Since every kind of information - coming from inside or outside the body, material or relational - is processed by a single integrated system, it follows the inability to determine cause-effect of one input within the cybernetic apparatus of that organism.

For cancer development, therefore, it is necessary to consider a summation of heterogeneous inputs that potentially represent risk factors. As seen above, some genetic hypotheses have been replaced by environmental evidence, but genetic factors are likely implicated in forms of cancer with familiarity. Conceptually - excluding extreme cases, such as acute radiation exposure, where it is convincing to consider only one genesis - cancer should be considered of multifactorial origin, as others authors claimed. Garssen [176] suggested the need to study the interactive effects of psychological, demographic and biomedical risk factors, concluding that the most important studies are still to be done. Holistic research would require probabilistic reasoning, suitable for mathematical models [185], which are increasingly used in medicine to optimize therapies but also for diagnosis and prognosis. There are almost 7000 computational models of cancer online currently, but they consider biological data only. Thus, a probabilistic model for multifactorial risk factors does not exist yet; but a holistic integrated model for the evaluation of cancer healing has been proposed, taking in consideration sociocultural, psychological, behavioural, and biomedical variables - also using informatics [186].

Thorough investigations can highlight chronic hopelessness [90] and long-term individual psychotherapy often leads to consciousness feelings of deep despair dating back to a long time before cancer [182]. Fundamental task of medicine is prevention more than therapy of overt disease. "Primary prevention of cancer depends on changing behaviors and lifestyle" [54] - a commitment that goes beyond the limits of biomedical science to enter into the understanding of incorrect habits with serious effects on health. Even when cancer occurs," Physical therapy alone is an emergency measure" [187].
This not only because of the psychosocial needs that are beginning to be recognized as important for the care of the whole patient (although they are still "often ignored or not defined as part of health care") [188]. Indeed Booth [34], referring to Elida Evans, connected cancer with a real or psychological loss, and conditioned the prognosis to the circumstance that the patient would find a satisfactory substitute. Lack of hope and dire need for relationships may be present together in cancer patients, who run the risk to be isolated by the technical equipment and mentality of a hospital, while they should be emotionally supported to prevent a definitive renunciation of life. Guidelines for an optimal healing environment have been prepared [189], where modifications of diet, lifestyle and psychosocial factors are joined to staff training for empathic listening and communication. The application of these recent guidelines is providing positive results and an increase in survival times.

In 1973, the process of replacing the lost relationship was called rehabilitation by Booth, who related spontaneous regressions of cancer to "a favorable change in the psychosocial situation of the patient" [190]. After the Simontons [191,192], Spiegel [193], and Fawzy's [194] studies, there is evidence that psychological supportive-expressive group therapy for cancer patients is associated with a survival increase of about two-fold among participants compared to statistical expectations. This research has been continued by Cunningham [195-197], who has shown the importance of participants involvement on survival. Despite their positive results, these psycho-oncological interventions (carried out in a few research centres) have not spread, above all because of mutual mistrust between clinicians of body and mind.

Persistent dualism - studying body or mind - is depriving research of fundamental variables involved in human cancer. A monistic-holistic perspective allows us to consider the whole individual; however, higher and lower levels of investigation are not incompatible. On the contrary, holism and reductionism should constitute co-operating and mutually dependent research programmes [198] in order to achieve a better prevention and therapy of cancer. Therefore, the implementation of integrated multidisciplinary research can provide the best answers.

\section{Competing Interests}

The author declares that he has no competing interest.

\section{References}

1. Brown TM. The rise and fall of American psychosomatic medicine. University of Rochester, New York Academy of Medicine. 2012.

2. Gadamer HG. The Enigma of Health: The Art of Healing in a Scientific Age. Stanford University Press. 1996.

3. Smuts JC. Holism and Evolution. New York; The Macmillan Company; 1926. doi: 10.5962/bhl.title.4568

4. Kowal SJ. Emotions as a cause of cancer: 18th and 19th century contributions. Psychoanal Rev. 1955; 42(3): 217-227.

5. Walsche WH. The Anatomy, Physiology, Pathology, and Treatment of Cancer. Boston, MA, Ticknor WD. 1844: 120.

6. LeShan L. Psychological states as factors in the development of malignant disease: A critical review. J Natl Cancer Inst. 1959; 22(1): 1-18. 
7. Reiser SJ. Medicine and the Reign of Technology. 1st edition. New York, NY: Cambridge University Press; 1981.

8. Hale NG. Freud and the Americans. The Beginning of Psychoanalysis in the United States, 1876-1917. 1st edition. New York, NY: Oxford University Press. 1971.

9. Taylor E. The Mystery of Personality. A History of Psychodynamic Theories. New York, NY: Springer; 2009: 19-47.

10. Taylor E. Jung before Freud, not Freud before Jung: the reception of Jung's work in American psychoanalytic circles between 1904 and 1909. J Anal Psycol. 1998; 43(1): 97-114. doi: 10.1111/1465-5922.00011

11. Jung CG. Experimental Researches (1904-1910). In: Read H, Fordham M, Adler G Collected Works, volume 2. Princeton, NJ: Princeton University Press; 1973.

12. Taylor E. The new Jung scholarship. Psychoanal Rev. 1996; 83(4): 547-568.

13. Mattson ME, Wertz FJ, Fogarty $H$, Klenck $M$, Zabriskie B (eds). Jung in the Academy and Beyond. The Fordham Lectures 100 Years Later. New Orleans, LA: Spring Journal Books; 2015.

14. Jelliffe SE. Sketches in Psychosomatic Medicine. New York, NY: Nervous and Mental Disease Monographs; 1939.

15. Burnham J, McGuire W. Jelliffe: American Psychoanalyst and Physician and His Correspondence with Sigmund Freud and C. G. Jung. Chicago, IL: University of Chicago Press; 1983.

16. Alexander FG, Selesnick ST. The History of Psychiatry: An Evaluation of Psychiatric Thought and Practice from Prehistoric Times to the Present. New York, NY: Harper \& Row; 1966: 262-265.

17. Levenson D. Mind, Body, and Medicine: A History of the American Psychosomatic Society. Philadelphia, PA: Williams \& Wilkins; 1994.

18. Jelliffe SE. The ecological principle in medicine (1935/1937). In: Sketches in psychosomatic medicine. New York, NY: Nervous and Mental Disease Monographs; 1939: 131-152.

19. Balenci M. Totality in Groddeck's and Jung's Conception: Es and Selbst. Int J Jungian Studies. 2018. doi: 10.1080/19409052.2018.1474127

20. Jelliffe $\mathrm{SE}$, Evans E. Psoriasis as an hysterical conversion symbolization. A preliminary report. New York Med J. 1916; 104: 1077-1084.

21. Jelliffe SE, Evans E. Psychotherapy and tuberculosis. Am Rev Tuberculosis. 1919; 3: 417-432.

22. Evans E. A Psychological Study of Cancer. New York, NY: Dodd, Mead \& Company; 1926.

23. Balenci M. Elida Evans' pioneering work for a Jungian approach to psychosomatics of cancer. Quadrant; 2019 (in press).

24. Jung CG. Psychological types (1921). In: Read H, Fordham M, Adler G (eds). Collected Works. Volume 6. Princeton, NJ: Princeton University Press; 1971: 3-495.

25. LeShan L. Some recurrent life history patterns observed in patients with malignant disease. J Nerv Ment Dis. 1956; 124: 460-465.

26. LeShan L. You Can Fight for Your Life: Emotional Factors in the Treatment of Cancer. New York, NY: M. Evans \& Company; 1980.

27. Chiozza LA. Why Do We Fall III? The Story Hiding in the Body. Madison, CT: Psychosocial Press; 1999.

28. Jung CG. The concept of the collective unconscious. In: Read $\mathrm{H}$, Fordham M, Adler G, McGuire W (eds). Collected Works, volume. 9/1. Princeton, NJ: Princeton University Press; 1980: 44.

29. Hediger H. Bemerkungen zum Raum-Zeit-System der Tiere. Schweiz Z Psychol. 1946; 5(4): 241-269.

30. Portmann A. Das Problem der Urbilder in biologischer Sicht. Eranos Jahrbuch. 1950; 18: 413-432.

31. Lorenz K. Behind The Mirror: A Search for a Natural History of Human Knowledge. London: Methuen \& Company; 1977.

32. Mayr E. The Growth of Biological Thought: Diversity, Evolution, and Inheritance. Cambridge, MA: The Belknap Press of Harvard University Press; 1982: 612
33. Stevens A. Archetype Revisited. An Updated Natural History of the Self London: Brunner-Routledge; 2002.

34. Booth G. The Cancer Epidemic: Shadow of the Conquest of Nature. New York, NY: The Edwin Mellen Press; 1979.

35. Wheeler J, McDonald Caldwell B. Psychological evaluation of women with cancer of the breast and of the cervix. Psychosom Med. 1955; 17(4): 256.

36. Levenson D. Mind, Body, and Medicine. A History of the American Psychosomatic Society. Philadelphia, PA: Williams \& Wilkins; 1994: 125-127.

37. Groddeck G. The Book of the It (1923). Mansfield Centre, CT: Martino Publishing; 2015.

38. Groddeck G. Von der psychischen Bedingtheit der Krebserkrankung (1934). In: Clauser G (ed). Psychoanalytische Schriften zur Psychosomatik. Wiesbaden: Limes Verlag; 1966: 380-385.

39. von Weizsäcker V. Der Gestaltkreis. Theorie und Einheit von Wahrnehmen und Bewegen. Leipzig: Thieme; 1947.

40. Hitzer $B$, León-Sanz P. The feeling body and its diseases: How cancer went psychosomatic in twentieth-century Germany. Osiris. 2016; 31(1): 67-93. doi: $10.1086 / 687591$

41. Burnham JC. Psychoanalysis and American Medicine: 1894-1918. Medicine, Science, and Culture. New York, NY: International Universities Press; 1968.

42. Engel GL. Psychological Development in Health and Disease. Philadelphia, PA \& London: WB. Saunders; 1962.

43. Engel GL. Selection of clinical material in psychosomatic medicine. The need for a new physiology. Psychosom Med. 1954; 16(5): 368-373.

44. Engel GL. The clinical application of the biopsychosocial model. Am J Psychiatry. 1980; 137(5): 535-544.

45. Taylor GJ. Mind-body-environment: George Engel's psychoanalytic approach to psychosomatic medicine. Austral N Z J Psychiatry. 2002; 36(4): 449-457.

46. Engel GL, Schmale AH. Psychoanalytic theory of somatic disorder Conversion, specificity, and the disease onset situation. J Am Psychoanal Assoc. 1967; 15(2): 344-365. doi: 10.1177/000306516701500206

47. Engel GL. A life setting conducive to illness: the giving-up- given-up complex. Ann Intern Med. 1968; 69(2): 293-300. doi: 10.7326/0003-4819-69-2-293

48. Engel GL, Schmale AH. Conservation-withdrawal: a primary regulatory process for organismic homeostasis. Ciba Found Symp. 1972; 8: 57-75.

49. Cannon WB. Bodily Changes in Pain, Hunger, Fear, and Rage. New York, NY: Appleton-Century-Crofts; 1927.

50. Schmale AH, Iker HP. The affect of hopelessness and the development of cancer. I. Identification of uterine cervical cancer in women with atypical cytology. Psychosom Med. 1966; 28(5): 714-721.

51. Schmale AH, Iker HP. Hopelessness as a predictor of cervical cancer. Soc Sci Med. 1971; 5(2): 95-100.

52. Shorter E. The history of the biopsychosocial approach in medicine: before and after Engel. In: White P (ed). Biopsychosocial Medicine. An Integrated Approach to Understanding Illness. New York, NY: Oxford University Press; 2005: 1-11. doi: 10.1093/med:psych/9780198530343.001.0001

53. Ader R, Cohen N. Behaviorally conditioned immunosuppression. Psychosom Med. 1975; 37(4): 333-340.

54. Holland JC. History of psycho-oncology: Overcoming attitudinal and conceptual barriers. Psychosom Med. 2002; 64(2): 206-221.

55. Ader, R (ed.). Psychoneuroimmunology. 1st edition. Orlando, FL: Academic Press; 1981.

56. Pert $C B$, Ruff MR, Weber RJ, Herkenham M. Neuropeptides and their receptors: A psychosomatic network. J Immunol. 1985; 135(2): 820-826.

57. Blalock JE, Bost KL, Smith EM. Neuroendocrine peptide hormones and their receptors in the immune system. Production, processing and action. J Neuroimmunol. 1985; 10(1): 31-40.

58. Blalock JE. A molecular basis for bidirectional communication between the immune and neuroendocrine systems. Physiol Rev. 1989; 69(1): 1-32 doi: 10.1152/physrev.1989.69.1.1 
59. Pert $\mathrm{CB}$, Dreher $\mathrm{HE}$, Ruff MR. The psychosomatic network: foundations of mind-body medicine. Altern Ther Health Med. 1998; 4(4): 30-41.

60. Kielcolt-Glaser JK, Glaser R. Psychoneuroimmunology and cancer: Fact or fiction? Eur J Cancer. 1999; 35(11): 1603-1607.

61. Kielcolt-GlaserJK, McGuire L, Robles TF, Glaser R. Psychoneuroimmunology: Psychological influences on immune function and health. $J$ Consult Clin Psychol. 2002; 70(3): 537-547.

62. Agnew CR, South SC. Interpersonal Relationships and Health: Social and Clinical Psychological Mechanisms. 1st Edition. New York, NY: Oxford University Press; 2014: 17.

63. Solomon GF. The development and history of psychoneuroimmunology. In: Koenig HG, Cohen HJ (eds.). The Link between Religion and Health: Psychoneuroimmunology and the Faith Factor. New York, NY: Oxford University Press; 2002: 31-42.

64. Vitkovic L, Koslow SH. Neuroimmunology \& Mental Health. A Report on Neuroimmunology Research. Rockville, MD: National Institute of Mental Health; 1994.

65. Lewis CE, O'Brien RM, Barraclough J (eds). The Psychoimmunology of Cancer. 2nd Edition. New York, NY: Oxford University Press; 2002.

66. Cutler $M$. The nature of the cancer process in relation to a possible psychosomatic influence. In: Gengerelli JA, Kirkner FJ (eds). The Psychological Variables in Human Cancer. A Symposium Presented at the Veterans Administration Hospital. Long Beach, California, Berkeley \& Los Angeles, CA: University of California Press. 1954: 1-13.

67. Kissen DM, LeShan LL (eds). Psychosomatic Aspects of Neoplastic Disease. London: Pitman Medical Publishing; 1964.

68. Bahnson CB, Kissen DM. Psychophysiological Aspects of Cancer. Ann NY Acad Sci. 1966; 125(3): 773-1055.

69. Bahnson CB. Second Conference on Psychophysiological Aspects of Cancer. Ann NY Acad Sci. 1969; 164(2): 307-634.

70. LeShan LL, Worthington RE. Personality as a factor in the pathogenesis of cancer: a review of the literature. Brit J Med Psychol. 1956; 29(1): 49-56. doi: 10.1111/j.2044-8341.1956.tb01188.x

71. LeShan LL. Some observations on the problem of mobilizing the patient's will to live. In: Kissen DM, LeShan LL (eds). Psychosomatic Aspects of Neoplastic Disease. London: Pitman Medical Publishing; 1964: 109-120.

72. LeShan L. An emotional life-history pattern associated with neoplastic disease. Ann NY Acad Sci. 1966; 125(3): 780-793.

73. Baltrusch HJF. Problems of research strategy in the psychosomatic approach towards malignant hemic disease. In: Kissen DM, LeShan LL (eds). Psychosomatic Aspects of Neoplastic Disease. London: Pitman Medical Publishing; 1964: 170-183.

74. Baltrusch HJF. Research on the personality of cancer patients. Riza Scienze. 1984; 5: 64-79.

75. Thomas C. Cancer and the youthful mind: A forty year perspective. Adv Mind Body Med. 1988; 5(2): 42-58.

76. Bahnson $\mathrm{CB}$, Bahnson $\mathrm{MB}$. Cancer as an alternative to psychosis: $\mathrm{A}$ theoretical model of somatic and psychologic regression. In: Kissen DM, LeShan LL (eds). Psychosomatic Aspects of Neoplastic Disease. London: Pitman Medical Publishing; 1964: 184-202.

77. Bahnson CB. Psychophysiological complementary in malignancies: Past work and future vistas. Ann NY Acad Sci. 1969; 164(2): 319-334.

78. Grinker RR. Toward a Unified Theory of Human Behavior. New York, NY: Basic Books; 1956.

79. Grinker RR. Psychosomatic aspects of the cancer problem. Ann NY Acad Sci. 1966; 125(3): 876-882.

80. Bahnson CB. Epistemological perspectives of physical disease from the psychodynamic point of view. Am J Publ Health. 1974; 64(11):1034-1040. doi: 10.2105/AJPH.64.11.1034

81. Bahnson $C B$, Bahnson MB. Denial and repression of primitive impulses and of disturbing emotions in patients with malignant neoplasms. In: Kissen DM, LeShan LL (eds). Psychosomatic Aspects of Neoplastic Disease. London: Pitman Medical Publishing; 1964: 42-62.
82. Bahnson CB, Bahnson MB. Role of the ego defenses: Denial and repression in the etiology of malignant neoplasm. Ann NY Acad Sci. 1966; 125(3): 827-845.

83. Bahnson CB, Bahnson MB. Ego defenses in cancer patients. Ann NY Acad Sci. 1969; 164(2): 546-557.

84. Hale NG. The Rise and Crisis of Psychoanalysis in the United States. Freud and the Americans, 1917-1985. New York, NY: Oxford University Press; 1995: 322-327.

85. Schwartz GE, Weiss SM. Behavioral medicine revisited. An amended definition. J Behav Med. 1978; 1(3): 249-251.

86. Friedman M, Rosenman RH. Type A Behavior and Your Heart. New York, NY: Ballantine Books; 1981.

87. Temoshok L, Fox BH. Coping styles and other psychosocial factors related to medical status and to prognosis in patients with cutaneous malignant melanoma. In: Fox BH, Newberry BH (eds). Impact of Psychoendocrine Systems in Cancer and Immunity. Lewiston, NY: Hogrefe; 1984: 258-287.

88. Kneier AW, Temoshok L. Repressive coping reactions in patients with malignant melanoma as compared to cardiovascular disease patients. J Psychosom Res. 1984; 28(2): 145-155.

89. Temoshok L. Personality, coping style, emotion, and cancer: Toward an integrative model. Cancer Surv. 1987; 6(3): 545-567.

90. Temoshok L, Dreher H. The Type C Connection: The Behavioral Links to Cancer and Your Health. New York, NY: Random House; 1992.

91. Greer S, Morris T. Psychological attributes of women who develop breast cancer: A controlled study. J Psychosom Res. 1975; 19(2): 147-153.

92. Greer S, Morris T, Pettingale KW. Psychological response to breast cancer: Effect on outcome. Lancet. 1979; 2(8146): 785-787.

93. Van Vugt $M$, Van Lange PAM. The altruism puzzle: Psychological adaptations for prosocial behavior. In: Shaller M, Simpson JA, Kenrick DT, eds. Evolution and Social Psychology. New York, NY \& Hove, UK: Psychology Press; 2006: 237-261.

94. Dreher H. Mind-Body Unity. A New Vision for Mind-Body Science and Medicine. Baltimore, MD: Johns Hopkins University Press; 2003: 155-200.

95. Simonton OC, Matthews-Simonton S, Creighton JL. Getting Well Again. A Step-by-Step, Self-Help Guide to Overcoming Cancer for Patients and Their Families. London: Bantam Books; 1978.

96. Balenci M. II Sé. In: Carotenuto A, ed. Treaty of Analytical Psychology, 2. Turin: UTET; 1992: 207-243.

97. Hannah B. Encounters with the Soul: Active Imagination as Developed by C.G. Jung. Santa Monica, CA: Sigo: 1981.

98. Jung CG. Psychological factors determining human behavior (1937). In: Read H, Fordham M, Adler G, McGuire W (eds). Collected Works, volume 8. Princeton, NJ: Princeton University Press; 1969: 114-125.

99. Riesman D. The Lonely Crowd: a Study of the Changing American Character (abridged edition). New Haven, CT: Yale University Press; 1961.

100. Sardello RJ. The suffering body of the city. Cancer, heart-attack, and herpes. Spring. 1983; 145-164.

101. Jung CG. The spiritual problem of modern man (1928/1931). In: Read $H$, Fordham M, Adler G, McGuire W, eds. Collected works, volume 10 . Princeton, NJ: Princeton University Press; 1970: 74-96.

102. Neumann E. Die Sinnfrage und das Individuum. In: Fröbe-Kapteyn $O$, ed. Eranos-Jahrbuch 1957: Mensch und Sinn. Zürich: Rhein-Verlag; 1958: 11-55.

103. Lorenz K. Civilized Man's Eight Deadly Sins. London: Methuen \& Company; 1974.

104. Fromm E. Escape from Freedom (1941/1969). New York, NY: Henry Holt \& Company; 1994: 183-204.

105. Whitmont EC. The Symbolic Quest. Basic Concepts of Analytical Psychology. Princeton, NJ: Princeton University Press; 1991: 157.

106. Ammon G. Psychoanalysis and Psychosomatics. New York, NY: Springer; 1979: 82.

107. Doll R, Peto R. The causes of cancer: Quantitative estimates of avoidable risks of cancer in the United States today. J Natl Cancer Inst. 1981; 66(6): 1191-1308. 
108. Rothenberg R. The causes of cancer, revisited. Ann Epidemiol. 2015; 25(3): 215-216. doi: 10.1016/j.annepidem.2014.11.012

109. Blot WJ, Tarone RE. Doll and Peto's quantitative estimates of cancer risks: Holding generally true for 35 years. J Natl Cancer Inst. 2015; 107(4): doi:10.1093/jnci/djv044

110. Song M, Giovannucci EL. RE: Doll and Peto's quantitative estimates of cancer risks: Holding generally true for 35 years. J Natl Cancer Inst. 2015; 107(10): doi:10.1093/jnci/djv240

111. National Research Council. Diet, Nutrition, and Cancer: Directions for Research. Washington, DC: National Academies Press; 1983. doi: $10.17226 / 381$

112. Carroll KK, Khor HT. Dietary fat in relation to tumorigenesis. Prog Biochem Pharmacol. 1975; 10: 308-353.

113. Buell P. Changing incidence of breast cancer in Japanese-American women. J Natl Cancer Inst. 1973; 51(5): 1479-1483.

114. Locke FB, King $\mathrm{H}$. Cancer mortality risk among Japanese in the United States. J Natl Cancer Inst. 1980; 65(5): 1149-1156. doi: 10.1093/jnci/65.5.1149

115. Armstrong D, Doll R. Environmental factors and cancer incidence and mortality in different countries, with special reference to dietary practices. Int J Cancer. 1975; 15(4): 617-631.

116. China-Cornell-Oxford Project on Nutrition, Environment and Health at Cornell University. Division of Nutritional Sciences - Cornell University, Ithaca, NY

117. Chen J, Campbell TC, Li J, Peto R (eds). Diet, Life-style and Mortality in China: A Study of the Characteristics of 65 Chinese Counties. New York, NY: Oxford University Press, Cornell University Press \& People's Medical Publishing House; 1990.

118. Weinhouse $S$, Bal DG, Adamson $R$, et al. American Cancer Society: Guidelines on diet, nutrition, and cancer. The Work Study Group on Diet, Nutrition, and Cancer. CA Cancer J Clin. 1991; 41(6): 334-338.

119. Willett WC. Diet, nutrition, and avoidable cancer. Environ Health Perspect. 1995; 103: 165-170. doi: 10.1289/ehp.95103s8165

120. Go VL, Wong DA, Butrum R. Diet, nutrition and cancer prevention: Where are we going from here? J Nutr. 2001; 131(11): S3121-S3126. doi: 10.1093/ jn/131.11.3121S

121. WHO/FAO. Diet, Nutrition and the Prevention of Chronic Diseases. Geneva: World Health Organization. 2003: 95-104.

122. Key TJ, Schatzkin A, Willett WC, Allen NE, Spencer EA, Travis RC. Diet, nutrition and the prevention of cancer. Public Health Nutr. 2004; 7(1A): 187-200.

123. World Cancer Research Fund/American Institute for Cancer Research. Food, Nutrition, Physical Activity, and the Prevention of Cancer: a Global Perspective. Washington, DC: AICR, 2007.

124. World Cancer Research Fund/American Institute for Cancer Research. Diet, Nutrition, Physical Activity, and Cancer: a Global Perspective. A summery of the Third Expert Report. Washington, DC: AICR, 2018.

125. Rossi EL. The Psychobiology of Mind-Body Healing: New Concepts of Theraupeutic Hypnosis. New York, NY: Norton \& Company; 1993: 240-246.

126. Burnet FM. Immunology, Aging and Cancer: Medical Aspects of Mutation and Selection. San Francisco, CA: W. H. Freeman \& Company; 1976.

127. Schulenburg $H$, Kurtz J, Moret $Y$, Siva-Jothy MT. Introduction. Ecological immunology. Philos Trans R Soc Lond B Biol Sci. 2009; 364(1513): 3-14. doi: 10.1098/rstb.2008.0249

128. Tauber Al. The Immune Self: Theory or Metaphor? (Cambridge Studies in Philosophy and Biology). New York, NY: Cambridge University Press; 1994: 156-180

129. Cohen IR. Tending Adam's Garden: Evolving the Cognitive Immune Self. San Diego, CA: Elsevier Academic Press; 2004.

130. Fridman WH. Le cerveau mobile. De l'immunité au système immunitaire. Paris: Hermann; 1991.

131. Tauber Al. The immune system and its ecology. Philos Sci. 2008; 75(2): 224-245.
132. Bowlby J. Attachment and Loss. Volume 1: Attachment. 2nd Edition. New York, NY: Basic Books; 1982.

133. Spitz RA, Wolf KM. Anaclitic depression: An inquiry into the genesis of psychiatric conditions in early childhood, II. The Psychoanalytic Study of the Child. 1946; 2: 313-342.

134. Spitz RA. The First Year of Life. A Psychoanalytic Study of Normal and Deviant Development of Object Relations. Madison, CT: International Universities Press. 1965.

135. Harlow HF. The nature of love. American Psychologist. 1958; 13: 673-685.

136. Harlow HF, Zimmermann RR. Affectional responses in the infant monkey. Science. 1959; 130: 421-432.

137. Bowlby J. Attachment and Loss. Volume 3: Loss: Sadness and Depression. London: Hogarth Press; 1980.

138. Hofer MA. Toward a developmental basis for disease predisposition: The effects of early maternal separation on brain, behavior, and cardiovascular system. In: Weiner $\mathrm{H}$, Hofer MA, Stunkard AJ (eds). Brain, Behavior, and Bodily Disease. New York, NY: Raven Press; 1981: 209-228.

139. Hofer MA. On the nature and consequences of early loss. Psychosom Med. 1996; 58(6): 570-581.

140. Hofer MA. Psychobiological roots of early attachment. Curr Dir Psychol Sci. 2006; 15(2): 84-88. doi: 10.1111/j.0963-7214.2006.00412.x

141. Hofer MA. Relationships as regulators: A psychobiologic perspective on bereavement. Psychosom Med. 1984; 46(3): 183-197.

142. Winberg J. Mother and newborn baby: Mutual regulation of physiology and behavior- A selective review. Dev Psychobiol. 2005; 47(3): 217-229. doi: $10.1002 /$ dev.20094

143. Field T. Attachment as psychobiological attunement: Being on the same wavelength. In: Reite M, Field T (eds). The Psychobiology of Attachment and Separation. Orlando, FL: Academic Press; 1985: 415-454.

144. Field T. The effects of mother's physical and emotional unavailability on emotion regulation. In: Fox NA (ed.) The Development of Emotion Regulation: Biological and Behavioral Considerations. Chicago, IL: University of Chicago Press; 1994: 208-227. doi: 10.1111/j.1540-5834.1994.tb01286.x

145. Brockington I. Motherhood and Mental Health. New York, NY: Oxford University Press; 1996.

146. Sbarra DA, Hazan C. Coregulation, dysregulation, self-regulation: An integrative analysis and empirical agenda for understanding adult attachment, separation, loss, and recovery. Pers Soc Psychol Rev. 2008; 12(2): 141-167. doi: 10.1177/1088868308315702

147. Field T. Relationships as regulators. Psychology. 2012; 3(6): 467-479. doi: 10.4236/psych.2012.36066

148. Schore AN. Affect Regulation and the Origin of the Self. The Neurobiology of Emotional Development. New York, NY: Routledge; 2016: 435.

149. Grassi L, Molinari S. Family affective climate during the childhood of adult cancer patients. J Psychosoc Oncol. 1986; 4(3): 53-62. doi: 10.1300/ J077v04n03_05

150. Kerr ME. Cancer and the family emotional system. In: Goldberg JG (ed) Psychotherapeutic Treatment of Cancer Patients. New Brunswick, NJ: Transaction Publishers; 1990: 273-315.

151. Tacón AM. Attachment and cancer: A conceptual integration. Integr Cancer Ther. 2002; 1(4): 371-381. doi: 10.1177/1534735402238188

152. Pert, C. B. (1986). The wisdom of the receptors: Neuropeptides, the emotions, and bodymind. Advances. 1986; 3(3): 8-16.

153. von Bertalanffy L. The mind-body problem: A new view. Psychosom Med. 1964; 26(1): 29-45

154. Zabriskie B. Energy and emotion: C.G. Jung's Fordham declaration. In: Mattson ME, Wertz FJ, Fogarty $H$, Klenck M, Zabriskie B (eds). Jung in the Academy and Beyond. The Fordham Lectures 100 Years Later. New Orleans, LA: Spring Journal Books; 2015: 37-49.

155. Atmanspacher $\mathrm{H}$. Dual-aspect monism à la Pauli and Jung. J Conscious Stud. 2012; 19(9-10): 96-120. 
156. Jung CG. On synchronicity (1951). In: Read H, Fordham M, Adler G, McGuire W (eds). Collected Works. Volume 8. Princeton, NJ: Princeton University Press; 1969: 520-531.

157. Jung CG. Synchronicity: An acausal connecting principle (1952). In: Read H, Fordham M, Adler G, McGuire W (eds). Collected Works. Volume 8. Princeton, NJ: Princeton University Press; 1969: 417-519.

158. Balenci M. Alcune osservazioni sulla tipologia junghiana. In: Carotenuto $A$, Balenci M (eds). Pluralità e convergenza. Rome: Kappa; 1995: 17-34.

159. Goldberg JG. Deceits of the Mind and Their Effects on the Body. New Brunswick, NJ: Transaction Publishers; 1991: 155-178.

160. Meier CA. Soul and Body. Essays on the Theories of C.G. Jung. San Francisco, CA: Lapis Press; 1986: 242-258.

161. Eysenck HJ. The structure of human personality (1953). London: Methuen \& Company; 1970.

162. Kissen DM, Eysenck HJ. Personality in male lung cancer patients. J Psychosom Res. 1962; 6(2): 123-127. doi: 10.1016/0022-3999(62)90062-4

163. Coppen AJ, Metcalfe M. Cancer and extroversion. In: Kissen DM, LeShan LL (eds). Psychosomatic aspects of neoplastic disease. London: Pitman Medical Publishing; 1964: 30-34.

164. Hagnell $\mathrm{O}$. The premorbid personality of persons who develop cancer in a total population investigated in 1947 and 1957. Ann NY Acad Sci. 1966; 125(3): 846-855.

165. Eysenck HJ. The prediction of death from cancer by means of personality/ stress questionnaire: Too good to be true? Percept Mot Skills. 1990; 71(1): 216-218. doi: 10.2466/pms.1990.71.1.216

166. Eysenck HJ. Prediction of cancer and coronary heart disease mortality by means of a personality inventory: Results of a 15-year follow-up study. Psychol Rep. 1993; 72(2): 499-516. doi: 10.2466/pr0.1993.72.2.499

167. Selye H. A syndrome produced by diverse nocuous agents. Nature. 1936; 138(3479): 32.

168. Selye H. Stress and the General Adaptation Syndrome. Br Med J. 1950; 1(4667): 1383-1392.

169. Dhabhar FS, McEwen BS. Bi-directional effects of stress on immune function: possible explanations for salubrious as well as harmful effects. In: Ader R (ed). Psychoneuroimmunology. Volume 2, 4th edition. Burlington, MA: Elsevier Academic Press; 2007: 723-760. doi: 10.1016/ B978-012088576-3/50041-1

170. Lightman S. Can neurobiology explain the relationship between stress and disease? In: White P (ed). Biopsychosocial Medicine. An Integrated Approach to Understanding IIIness. New York, NY: Oxford University Press; 2005: 103-116.

171. Rabin B.Stress:Asystem ofthewhole.In:AderR(ed).Psychoneuroimmunology, volume. 2. 4th edition. Burlington, MA: Elsevier Academic Press; 2007: 709-722.

172. Felitti VJ, Anda RF, Nordenberg D, et al. Relationship of childhood abuse and household dysfunction to many of the leading causes of death in adults. The Adverse Childhood Experiences (ACE) Study. Am J Prev Med. 1998; 14(4): 245-258.

173. Felitti VJ. The relation between adverse childhood experiences and adult health: Turning gold into lead. Perm J. 2002; 6(1): 44-47.

174. Brown DW, Anda RF, Felitti VJ, et al. Adverse childhood experiences are associated with the risk of lung cancer: A prospective cohort study. BMC Public Health. 2010; 10(1): 20-32. doi: 10.1186/1471-2458-10-20

175. Chida Y, Hamer M, Wardle J, Steptoe A. Do stress-related psychosocial factors contribute to cancer incidence and survival? Nat Clin Pract Oncol. 2008; 5(8): 466-475. doi: 10.1038/ncponc1134

176. Garssen B. Psychological factors and cancer development: Evidence after 30 years of research. Clin Psychol Rev. 2004; 24(3): 315-338. doi: 10.1016/j. cpr.2004.01.002

177. Zachariae R. Psychoneuroimmunology: A bio-psycho-social approach to health and disease. Scand J Psychol. 2009; 50(6): 645-651. doi: 10.1111/j.1467-9450.2009.00779.x
178. Cunningham AJ. Mind, body, and immune response. In: Ader R (ed). Psychoneuroimmunology. 1st edition. Orlando, FL: Academic Press; 1981 609-617.

179. Cohn Bolletino R, LeShan LL. Cancer. In: Watkins A (ed). Mind-Body Medicine. A Clinician's Guide to Psychoneuroimmunology. New York, NY: Churchill Livingstone; 1997: 87-111.

180. de la Peña AM. The Psychobiology of Cancer: Automatization and Boredom in Health and Disease. New York, NY: Praeger Publishers; 1983: 1-16.

181. Pert C, Dienstfrey $H$. The neuropeptide network. In: Pierpaoli W, Spector $\mathrm{NH}$ (eds). Neuroimmunomodulation: Interventions in Aging and Cancer. Ann NY Acad Sci. 1988; 521(1): 189-194.

182. LeShan LL. Cancer as a Turning Point: A Handbook for People with Cancer, Their Families, and Health Professionals. Revised edition. New York, NY Plume; 1994.

183. Greer S, Watson M. Towards a psychobiological model of cancer: psychological considerations. Soc Sci Med. 1985; 20(8): 773-777. doi: 10.1016/0277-9536(85)90330-2

184. von Bertalanffy L. General System Theory. Foundations Development Applications. Harmondsworth, UK: Penguin Books; 1968.

185. Husmeier D, Dybowski R, Roberts S (eds). Probabilistic Modeling in Bioinformatics and Medical Informatics. London, Springer-Verlag; 2005.

186. Jonas WB, Beckner W, Coulter I. Proposal for an integrated evaluation model for the study of whole systems health care in cancer. Integr Cancer Ther. 2006; 5(4): 315-319. doi: 10.1177/1534735406295565

187. Booth G. Irrational complications of the cancer problem. Am J Psychoanal. 1965; 25(1): 41-55. doi: 10.1007/BF01872030

188. Adler NE. Preface. In: Adler NE, Page AEK (eds). Cancer Care for the Whole Patient: Meeting Psychosocial Heath Needs. Washington, DC: The National Academies Press; 2008: xi.

189. Block Kl, Block P, Gyllenhaal C. The role of optimal healing environments in patients undergoing cancer treatment: Clinical research protocol guidelines. J Altern Complement Med. 2004; 10(suppl 1): s157-s170.

190. Booth G. Psychobiological aspects of "spontaneous" regressions of cancer. J Amer Acad Psychoanal. 1973; 1(3): 303-317.

191. Achterberg J, Matthews-Simonton S, Simonton OC. Psychology of the exceptional cancer patient: A description of patients who outlive predicted life expectancies. Psychotherapy: Theory, Research \& Practice. 1977; 14(4): 416-422. doi: 10.1037/h0087514

192. Simonton OC, Matthews-Simonton S, Sparks TF. Psychological intervention in the treatment of cancer. Psychosomatics. 1980; 21(3): 226-227, 231-233.

193. Spiegel D, Bloom J, Kraemer HC, Gottheil E. Effect of psychosocial treatment on survival of patients with metastatic breast cancer. Lancet. 1989; 2(8668): 888-891.

194. Fawzy Fl, Fawzy NW, Hyun CS, et al. Malignant melanoma. Effects of an early structured psychiatric intervention, coping, and affective state on recurrence and survival 6 years later. Arch Gen Psychiatry. 1993; 50(9): 681-689.

195. Cunningham AJ. The influence of mind on cancer. Can Psychol. 1985; 26(1): 13-29. doi: 10.1037/h0080019

196. Cunningham AJ, Watson K. How psychological therapy may prolong survival in cancer patients: New evidence and a simple theory. Integr Cancer Ther. 2004; 3(3): 214-229. doi: 10.1177/1534735404267553

197. Cunningham AJ. Group psychological therapy: An integral part of care for cancer patients. Integr Cancer Ther. 2002; 1(1): 67-75. doi: 10.1177/153473540200100116

198. Looijen RC. Holism and Reductionism in Biology and Ecology. The Mutual Dependence of Higher and Lower Level Research Programmes. Dordrecht, The Netherlands: Kluwer Academic Publishers; 2000. 